\title{
Needs Analysis of English for Aeronautical Engineering Purposes at STT Adisutjipto Yogyakarta
}

\author{
Dewanti Ratna Pertiwi \\ Sekolah Tinggi Teknologi Adisutjipto \\ dewanti_stta@yahoo.co.id
}

\begin{abstract}
In the context of ESP, needs analysis is the first step to develop a program. Needs analysis is conducted to investigate the present students' mastery and the need of the future work field. This study aims to investigate the needs analysis of English for aeronautical engineering. The study employed a survey technique in the form of distributing questionnaires and interview for the lecturers, and centre of quality insurance. Indonesian qualification framework to standardize the graduate of aeronautical engineering with the national criteria is used as the source of developing the research instruments. The result of the study is expected to be able to build the foundation of developing better English course for aeronautical engineering students.
\end{abstract}

Keywords: need analysis, ESP, aeronautic

\section{Introduction}

The first part of this research is written to describe the background of the problems containing the issues related to English for Aeronautical Engineering Purposes (henceforth EAEP) as the research foundation. It includes background, problem identification, problem limitation, problem formulation, research goal, and research benefit.

\section{Background}

A number of methods and strategies have been applied and adopted to facilitate students' development to master English in higher education. One of the goals set by most colleges and universities is to prepare the students to be ready to face global competiveness and to become professionals in their fields. It is unavoidable that most job vacancies need English proficiency as a basic requirement when companies expand internationally. Considering this objective, traditional English focusing on the four main skills; listening, speaking, reading, and writing is inadequate to prepare students for work. Therefore, English for specific purposes (ESP) emerges to facilitate the students to be well prepared to face global competitiveness in their future professional development.

As one of the fields under ESP context, English for aeronautical engineering purposes (EAEP) is interesting to be explored more deeply. Being responsible for the aircraft design, construction, and operation, aeronautic engineers have big roles in the air transportation safety and development. Hence, the graduates of aeronautical engineering department have to have adequate capability professionally. To achieve this objective, it is important to 
provide the students with effective materials, based on their practical needs, in the syllabus design and the course development. Thus, one of the challenging jobs of aeronautical engineering course developer is to identify the needs of the learner and then design the specific course. (Basturkmen: 2010).

Contextually, Indonesian education holds Indonesian qualification framework (kerangka kualifikasi nasional Indonesia, KKNI); a system connecting education and training to develop qualified and certified human resources through formal and non formal education, career training, and career experience. Since this research will focus on undergraduate level students, qualifications of Level 6 become the references to discuss this.

\section{Identification of the problems}

There are basically two things that the graduates of aeronautical engineering should have to be able to compete globally; aeronautics matters through English and supported by qualifications of Level 6 . It is no doubt that aeronautical engineering students have sufficient knowledge of their subject matter. However, the problems appear when they have to use the knowledge in English. The students can learn English through English courses and trainings outside the college in order to improve their English and prepare for their job hunting. Nevertheless, so far, it is not easy to selectively choose language programs that suit their needs. Therefore, a design of effective English course to solve this problem should be created.
An effective English course should be designed based on students' needs. It is expected that students are able to gain knowledge and skills of the language so they can be professional engineers in the future. Considering that objective, investigating students' needs becomes the foundation of developing an effective course. Contextually, it should pay attention to college's vision, department curriculum, tracer study, and Indonesian qualification framework.

\section{Problem formulation}

As an educational institution to prepare the students to be professional engineers, colleges and universities running aeronautical engineering departments should provide a sufficient course effectively. As aeronautics uses English often, either in theoretical books or in practical work for air transportation safety, a good aeronautical engineering department should provide the students with an effective English course based on the students' needs. By doing so, the graduates will be able to compete in the global competition and grow in professional development.

Conducting research on designing an effective English course for aeronautical engineering students will be very hard and time consuming and therefore will not be feasible for the researcher. Considering the limitations, this research will focus on the need analysis of English for aeronautical engineering purposes in STT Adisutjipto College. Thus, this research is intended to answer the problem formulation of 'What should 
be taught to aeronautical engineering department students to facilitate effective English course?'.

\section{Research Objective}

Corresponding to the formulation of the problem, the objective of this research is to identify the components that should be in the design of the English course materials for aeronautical engineering purposes to facilitate effective learning.

\section{Research Significance}

This research is expected to contribute to the following parties:

1. To the aeronautical engineering department, the researcher hopes that the result of this research can be an input of reference relating to materials design and development as well as English for specific purposes.

2. To other researchers who wish to develop English learning materials for aeronautical engineering subject or other subjects, the result of this research can be a reference as to what an effective material is like.

\section{Research Method}

This chapter subsequently comprises the type of study, the setting, the research procedure, the data collection technique, and the data analysis technique.

\section{Type of study}

As the goal of this study is to investigate the need analysis, a survey was employed. Needs analysis process is intended to collect information about the learners and define the target situation and the techniques of achieving specific teaching objectives. Since ESP is based on the need analysis, the learning objective is more obviously determined than in general English that sometimes the students will be more motivated in learning the subject matters which are related to the study (Otilia, 2015).

In addition, Neuman (2000) says a survey asks many people (called respondents) about their beliefs, opinions, characteristics, and behavior through the same questions. The researcher measured many variables, infer temporal order from questions about past behavior, experiences, and characteristics.

\section{Setting}

The research was conducted in Aeronautical Engineering Department, STT Adisutjipto, Yogyakarta. It took samples from 50 randomly chosen students from two different classes, head of the department, and the head of centre of quality insurance (Pusat Penjamin Mutu, P2M) - the board controlling the quality of education.

\section{Data collection technique}

In order to conduct a thorough needs analysis, a triangulation of questionnaires, interviews with lecturers, and observation during the course were conducted.

\section{Data analysis technique}

After collecting the entire data, each instrument was analyzed. The first step was analyzing the questionnaire responses that were put into table of percentage. After the table has been completed, the data were described. Secondly, the result 
of interviews with the lecturer (head of department) and the head of quality insurance centre were analyzed to find the deeper information. Thirdly, the result of observation during the course was analyzed to see the appropriate materials and techniques for future program.

\section{Discussion}

The main objective of this research is to analyze the English students' needs of aeronautical engineering. The English course design integrating subject matters and qualification framework is a relatively new proposed program as an attempt to develop engineering students' qualification and certification. The rationale behind this program is to improve Indonesian students' English proficiency and to prepare them to be able to compete in global competition. For that reason, theories of English for specific purposes, qualification framework, aeronautical engineering, and adult learning will be presented and discussed.

\section{English for Specific Purposes (ESP)}

ESP has been the subject of increasing attention in recent years. Differently taught from general English, ESP concentrates more on language in the thematic context than the grammar and language structure. The objective of learning in ESP is not merely integrating the four language skills; listening, speaking, reading, and writing but it is need analysis based. In designing an ESP instruction, grammatical functions, acquisition skills, terminology, specific functional content form the discipline are crucial. Even though ESP differs from general English, general English language content should also be integrated into the course since (a) content-related language cannot function without (b) general English language content (Chen, 2008). So (a) and (b) are integrated in such a way that students get both.

ESP is traditionally divided into two main areas; EAP (English for Academic Purposes) and EOP (English for Occupational Purposes). In EAP, the students learn English to enter professions, focusing on the language of academic performance preparing for future identified workplace needs. On the other hand, in EOP, the students are already employed in industrial sectors and learn English focusing on the language of job performance while preparing for identified employment opportunities. Under this circumstance, ESP varies into multiple fields and professions such as Tourism English, Medical English, Aeronautical English, and Business English. Basturkmen (2006) reports that subject specific language and target performance competencies are the two main objectives of ESP. Both objectives are necessary as the students need to gain their target workplace, academic, and professional development that they can be socially integrated into their discourse community.

In ESP, the teacher is often called as a practitioner to emphasize that ESP is not merely a teaching activity. Dudley-Evans \& St John 
(1998) describes a practitioner's responsibility might be done to meet the goal of ESP course. First, a practitioner conducts a research study toward his course program in terms of need analysis and course evaluation. Second, he or she provides a course design and the materials based on the need analysis conducted before teaching. Third, a practitioner facilitates a teaching process as a practical discipline to help students learn. Fourth, a practitioner elaborates the target language with the subject specialist to give the students opportunities to practice English in the working situation. Fifth, a practitioner evaluates the students' proficiency, the quality of teaching materials, and the course design that might be conducted on an on-going process and after the course has finished.

To meet the goal of each ESP program, including English for aeronautical purposes, need analysis before conducting the course should be conducted. Miyake and Themarco (2005) summarize the components of needs analysis as follows: 1) target situation analysis and objective needs, 2) wants, means, subjective needs, 3) present situation analysis, 4) lacks, 5) learning needs, linguistic analysis, discourse analysis, genre analysis, 6) the course goal, and 7) means analysis.

\section{Indonesian framework}

qualification

A qualification framework is proposed as an independent system that correlates educational sector and training to create qualified and certified human resources. A student may get a qualified status through formal education, while a certified status may be obtained through non formal, informal training, and working experience.

This research focuses on undergraduate students as the research subjects. Derived from Presidential Regulation Number 8, Year 2012, regarding Indonesian qualification framework, it is stated that undergraduate students should be qualified for the four Level 6 qualifications. First, the students should be able to apply a skill and use sciences, technology, and arts in their field to solve problems as well as being able to adapt to a particular situation. Second, the students should master professionally a particular theoretical field concept in general and specific and be able to formulate a procedural problem solving. Third, the students should be able to make a decision based on information analysis and data, and give instructions in selecting alternatives independently and in a group. Fourth, the students should be responsible in their individual and organizational working achievement.

\section{English for Aeronautical English Purposes (EAEP)}

In accordance with the need analysis components, in terms of target situation analysis and objective needs, the respondents; lecturer (head of department) and head of quality insurance centre showed that English lesson is intended to facilitate the students qualified to be aeronautical engineers and compete globally as quoted in the following statement answering the question "What should English course 
contribute to the students for their long term goals?"

\begin{tabular}{|l|l|}
\hline Lecturer & $\begin{array}{l}\text { "The students must be able to read and apply a manual and SOP because in } \\
\text { their work field, they will need to read manuals and SOP all the time to fix } \\
\text { aircraft." }\end{array}$ \\
\hline $\begin{array}{l}\text { Head of quality } \\
\text { insurance centre }\end{array}$ & $\begin{array}{l}\text { "The students must be able to understand the content of manual. Furthermore, } \\
\text { after being a qualified engineer, they must be able to develop their careers } \\
\text { even go international thus English course should facilitate the students with } \\
\text { English proficiency test (TOEFL, TOEIC, IELTS) preparation as well." }\end{array}$ \\
\hline
\end{tabular}

These data are in line with students' survey showed in the following table responding the statement "Learning
English is very important for my future career".

\begin{tabular}{|c|c|c|c|c|}
\hline Strongly Agree & Agree & $\begin{array}{c}\text { Neither Agree } \\
\text { Nor Disagree }\end{array}$ & Disagree & $\begin{array}{c}\text { Strongly } \\
\text { Disagree }\end{array}$ \\
\hline $88 \%$ & $12 \%$ & $0 \%$ & $0 \%$ & $0 \%$ \\
\hline
\end{tabular}

The English test preparation is considered necessary due to the tracer study that most graduates work in airline industry in which the qualifications need English proficiency. Considering that aeronautical engineering departments only have 6 credits for English; 2 credits each for semester one to three, offered as general English in semester 1 and technical English in semester 2 \& 3, therefore English proficiency test preparation should be excluded from intra curricular and conducted under language laboratory authorities proven by certificate. This program supports the Indonesian qualification framework to develop undergraduate students certified status through informal training. To make either formal or informal learning synergy, it is better to include the English proficiency test as one of the score contributions for intra curricular score that the students are encouraged to improve it.

To facilitate the students' wants, means, and subjective needs, presently, aeronautical engineering department requires the students to have a minimum of 450 TOEFL score as the qualification in the graduation requirement. In fact, the students feel it is difficult to achieve that since the training is not sufficient. The solution is reviewing the TOEFL cut-off score with the stake holders and increasing the number of English preparation training so that the students can reach the desired standard.

Discussing the present situation, the students feel that English is a challenge for them presently. Having taken English lesson since junior high school, the students responded to the questionnaire for statement "I think, English lesson is ...." as follows,

\begin{tabular}{|c|c|c|c|c|}
\hline Very Easy & Easy & $\begin{array}{c}\text { Neither Easy } \\
\text { nor Difficult }\end{array}$ & Difficult & Very Difficult \\
\hline $2 \%$ & $28 \%$ & $16 \%$ & $52 \%$ & $2 \%$ \\
\hline
\end{tabular}


This response might be the feedback for English lecturers on how to teach English lesson effectively. One breakthrough should be developed in making English more interesting through multimedia and e-learning. It is supported by the students' responses on the statement "I have been using Internet technology to learn English".

\begin{tabular}{|c|c|c|c|c|}
\hline Strongly Agree & Agree & $\begin{array}{c}\text { Neither Agree } \\
\text { nor Disagree }\end{array}$ & Disagree & $\begin{array}{c}\text { Strongly } \\
\text { Disagree }\end{array}$ \\
\hline $30 \%$ & $60 \%$ & $10 \%$ & $0 \%$ & $0 \%$ \\
\hline
\end{tabular}

The percentage is also in line with the lecturers' interview answering the questions "In which technique might the students be encouraged to learn English in this digital era?"

\begin{tabular}{|l|l|}
\hline Lecturer & $\begin{array}{l}\text { "The students are now very close with gadget technologies. Thus, it is } \\
\text { important to develop multimedia or e-learning project". }\end{array}$ \\
\hline $\begin{array}{l}\text { Head of } \\
\text { quality } \\
\text { insurance } \\
\text { centre }\end{array}$ & $\begin{array}{l}\text { "It is unavoidable that gadget becomes our prime tool right now. Everyone has } \\
\text { it. Thus, it is a good way to make English learning interesting through what } \\
\text { they touch every day; a hand phone, for example" }\end{array}$ \\
\hline
\end{tabular}

This data are supported by the students' performance in presenting a power point in groups on a selected topic about aeronautical fields. The students looked very enthusiastic in delivering the presentation. Those who were rarely involved in the classroom activity presented the materials enthusiastically.

Investigating the lacks, EAEP needs more authentic materials as stated in the lecturers' responses "What materials should facilitate English learning effectively?"

\begin{tabular}{|l|l|}
\hline Lecturer & $\begin{array}{l}\text { "Yes, the real materials. If it is not available, at least the lecturer should } \\
\text { provide the video of the real phenomena on aeronautical engineering or } \\
\text { picture, but would be better if the students see the authentic ones". }\end{array}$ \\
\hline $\begin{array}{l}\text { Head of } \\
\text { quality } \\
\text { insurance } \\
\text { centre }\end{array}$ & $\begin{array}{l}\text { "It is unavoidable that gadget becomes our prime tool right now. Everyone has } \\
\text { it. Thus, it is a good way to make English learning interesting through what } \\
\text { they touch every day; a hand phone, for example" }\end{array}$ \\
\hline
\end{tabular}

The students respond at the same point on the statement "I think, authentic materials in aeronautics are very important to describe the real condition".

\begin{tabular}{|c|c|c|c|c|}
\hline Strongly Agree & Agree & $\begin{array}{c}\text { Neither Agree } \\
\text { Nor Disagree }\end{array}$ & Disagree & $\begin{array}{c}\text { Strongly } \\
\text { Disagree }\end{array}$ \\
\hline $34 \%$ & $56 \%$ & $8 \%$ & $2 \%$ & $0 \%$ \\
\hline
\end{tabular}

In fact, the authentic materials in the Adisutjipto College of Technology are still limited. The solution is the students might access the materials in their internship under the English lecturer's given project.

As mentioned at the lecturers' opinion on the first question, the significant authentic materials are 
manuals and SOP. These materials are effective to improve the students' reading skill as reading skill is seen as the most frequently employed skill in aeronautical field. By improving the reading skill, the students might improve their technical terms that are very important in their career as an engineer. This goal is supported by the students' responses on the statement 1) "I think, preparation on technical terms is very important" and 2) "I think, reading skill on aeronautical engineering field is very important".

\begin{tabular}{|c|c|c|c|c|c|}
\hline No. & Strongly Agree & Agree & $\begin{array}{c}\text { Neither agree nor } \\
\text { disagree }\end{array}$ & Disagree & $\begin{array}{c}\text { Strongly } \\
\text { disagree }\end{array}$ \\
\hline 1 & $52 \%$ & $46 \%$ & $2 \%$ & $0 \%$ & $0 \%$ \\
\hline 2 & $58 \%$ & $42 \%$ & $0 \%$ & $0 \%$ & $0 \%$ \\
\hline
\end{tabular}

The data contribute to the next analysis; the learning needs, linguistic analysis, discourse analysis, and genre analysis. The interpretation is that reading skill on the manual and SOP is the most frequently employed skill. This skill might support other language competencies such as vocabulary development, grammar, listening, speaking, and writing. The lecturer and the head of quality insurance added the opinion on the question "How should grammar and vocabulary be taught?"

\begin{tabular}{|l|l|}
\hline Lecturer & $\begin{array}{l}\text { "I think in integration but still prioritize reading. Based on my } 7 \text { years } \\
\text { experience in airline, I had to read every single manual in aircraft } \\
\text { maintenance. And at the same way, I could improve my grammar and } \\
\text { vocabulary as there was a gap I should solve to comprehend the content of the } \\
\text { materials and I learnt grammar \& vocabulary automatically through reading" }\end{array}$ \\
\hline $\begin{array}{l}\text { Head of } \\
\text { quality } \\
\text { insurance } \\
\text { centre }\end{array}$ & $\begin{array}{l}\text { "I think the contextual reading will facilitate the vocabulary and grammar } \\
\text { mastery. Maybe the lecturer focuses on the reading comprehension while } \\
\text { checking the grammar \& vocabulary if necessary" }\end{array}$ \\
\hline
\end{tabular}

The last analysis falls upon the course and means analysis. As the goal of the graduates is getting appropriate jobs, it is important to facilitate the EAEP with job hunting materials. It is positively responded by the students on their questionnaire "I think, job hunting material (cover letter, CV, interview) in English is important in my future career".

\begin{tabular}{|c|c|c|c|c|}
\hline Strongly Agree & Agree & $\begin{array}{c}\text { Neither agree nor } \\
\text { disagree }\end{array}$ & Disagree & Strongly disagree \\
\hline $56 \%$ & $38 \%$ & $6 \%$ & $0 \%$ & $0 \%$ \\
\hline
\end{tabular}

The stake holders, lecturer and quality insurance, argue similarly as follows, the extracurricular lesson for the fresh graduate or the senior students as they 


\begin{tabular}{|l|l|}
\hline & will prepare job hunting already". \\
\hline $\begin{array}{l}\text { Head of } \\
\text { quality } \\
\text { insurance } \\
\text { centre }\end{array}$ & $\begin{array}{l}\text { "It is important but remember, give more simulations and practices instead of } \\
\text { theory. Also give awareness on the need of learning process." }\end{array}$ \\
\hline
\end{tabular}

Nowadays, there is no facility to give the students access in preparing their job hunting informally in the college. As this college periodically conducts recruitment tests with certain airlines, most students fail at the English test and English interview. Therefore, there should be a program to prepare the students to be ready for this test in terms of job hunting extracurricular lesson.

\section{Conclusion}

This paper attempts to identify the needs for English for aeronautical engineering students in STTA. The need analysis reveals what students, lecturer, and head of quality insurance think and require. Properly understanding their needs is essential in designing ESP course. The results are as follows:

a. English lesson is intended to facilitate the students qualified to be aeronautical engineers and compete globally

b. reviewing the TOEFL standard with the stake holders and increasing the English preparation training so that the students can reach the standard

c. most students feel English is difficult that the lecturer should find the effective technique

d. there is not yet multimedia and e-learning that might encourage the students to learn English

e. reading skill is the most frequently required skill in aeronautical field

f. there should be a program on job hunting in English

g. there should be synergy between formal and informal English training to prepare the students being engineers professionally

\section{References}

(2012). Lampiran Peraturan Presiden Republik Indonesia No. 8 Tahun 2012.

Basturkmen, H. (2006). Ideas and options in English for specific purposes. New Jersey: Lawrence Erlbaum Associates.

(2010). Developing Courses in English for Specific Purposes. Palgrave: New York.

Chen, C. M. (2008). The difficulty of university English courses and English for specific purposes: From the view of policy and administration. English Career, 28, 12-16.

Dudley-Evans, T., and St John, M. (1998). Developments in ESP: A multidisciplinary approach. Cambridge: CUP.

ISSN 2251-838X. Science Explorer Publications. Vol, 4 (5): 1014-1020.

Miyake, M. and John, T. (2005). Needs Analysis for Nursing Students Utilizing Questionnaires and Interviews. Kawasaki Journal of Medical Welfare. Volume II, No.1, 2005 23-24. 
Neuman, W. L. (2000). Social Research Methods: Qualitative and Quantitative Approaches. $4^{\text {th }}$ Ed. Allyn and Bacon: Boston.

Otilia, S. M. (2015). Needs Analysis in English for Specific Purposes. Annals of the ,Constantin Brâncuşi” University of Târgu Jiu, Economy Series, Issue 1, Volume II/2015 